\title{
PENGEMBANGAN BUKU CERITA BERGAMBAR BERBASIS LINGKUNGAN HIDUP PADA PEMBELAJARAN TEMATIK DI KELAS II SD/MI
}

\author{
Ayu Nur Shawmi \\ Nurhaidah Widiani \\ Afni Novita Dewi \\ UIN Raden Fatah Palembang \\ ayunurshawmi uin@,radenfatah.ac.id
}

\begin{abstract}
This research is motivated by the learning media carried out in schools that look less effective and less attractive.Because learning in the classroom does not use alternative media other than thematic books. From the existing problems, environmental-based picture story books were developed with the aim of (1) being able to produce picture story books with the help of correl draw applications and Photoshop soft ware. (2) knowing how appropriate the picture book media is. (3) to determine the feasibility ofvalidation response to the developed media. This type of research is Research and Development $(\mathrm{R} \& \mathrm{D})$ by using the steps of the research and development method according to Borg and Gall, modified by Sugiyono. The stages in research and development are potential and problems, collecting data, product design, product validation, product revision, product testing, and product revision. The results of the validation on picture story books by linguists obtained an average percentage of $90 \%$ with very feasible criteria, material experts obtained an average percentage of $97 \%$ with very feasible criteria, media experts obtained an average percentage of $92 \%$ with very feasible criteria. The assessment on the response of educators obtained an average percentage of $99 \%$ with very feasible criteria, and students' responses to small-scale trials at Wates State Elementary School in Central Lampung obtained an average percentage of $90 \%$ with very feasible criteria, as well as large-scale trials at schools in MI Al-Hikmah Bandar Lampung get an average percentage of $89 \%$ with very decent criteria. It was concluded that the environmental-based storybook with the help of correl draw applications and Photoshop soft ware for thematic learning subjects of class II SD / MI on the themeof caring for animals and plants developed were suitable for use as learning media.
\end{abstract}

Keywords: Learning Media, Story Books, Environment

\section{Abstrak}

Penelitian ini dilatar belakangi oleh media pembelajaran yang dilaksanakan di sekolah terlihat kurang efektif dan kurang menarik. Dari pemasalahan yang ada buku cerita bergambar dibuat kemudian dikembangkan menjadi buku cerita berbasis lingkungan hidup dengan tujuan untuk (1) dapat menghasilkan produk buku cerita bergambar dengan bantuan aplikasi correl draw dan soft ware potoshop. (2) mengetahui bagaimana kelayakan media buku cerita bergambar. (3) untuk mengetahui respon kelayakan validasi terhadap media yang dikembangkan. Jenis penelitian ini adalah Reseach and Development (R\&D) dengan menggunakan langkah-langkah metode penelitian dan pengembangan menurut Borg and Gall yang dimodifikasi oleh Sugiyono. Adapun tahapan dalam penelitian dan pengembangan yaitu potensi dan masalah, mengumpulkan data, desain produk, validasi produk, revisi produk, uji coba produk, dan revisi produk. Hasil validasi pada buku cerita bergambar oleh ahli bahasa memperoleh rata-rata persentase $90 \%$ dengan kriteria sangat layak, ahli materi memperoleh rata-rata persentase 97\% dengan kriteria sangat layak, ahli media memperoleh rata-rata persentase $92 \%$ dengan kriteria sangat layak. Penilaian pada respon pendidik memperoleh rata-rata persentase $99 \%$ dengan kriteria sangat layak, dan respon peserta didik pada uji coba skala kecil di SekolahDasar Negeri Wates Lampung Tengah memperoleh ratarata persentase $90 \%$ dengan kriteria sangat layak, serta uji coba skala besar pada sekolah di MI AlHikmah Bandar Lampung memperoleh rata-rata persentase $89 \%$ dengan kriteria sangat layak.

50| Jurnal Auladuna 
Disimpulkan bahwa buku cerita begambar berbasis lingkungan hidup dengan bantuan aplikasi correl draw dan soft ware potoshop mata pembelajaran tematik kelas II SD/MI pada tema merawat hewan dan tumbuhan yang dikembangkan layak digunakan sebagai media pembelajaran.

\section{Kata Kunci $\quad$ : Media Pembelajaran, Buku Cerita, Lingkungan Hidup}

\section{PENDAHULUAN}

Media pembelajaran sebagai salah satu fasilitas pembelajaran untuk memahami konsep abstrak sehingga siswa dapat melihat sesuatu yang nyata ${ }^{1}$. Penggunaan media diharapkan mampu menarik perhatian siswa dan memudahkan siswa dalam belajar. Media sebagai alat bantu guru dan peserta didik, dengan menggunakan media dapat membantu guru dan peserta didik dalam proses pembelajaran. Menurut Gagne, Briggs dan Wager pembelajaran merupakan serangkatan kegiatan yang dirancang untuk memungkinkan terjadinya proses belajar pada siswa. ${ }^{2}$ Guru dapat mencapai tujuan dari komponen pembelajaran yang harus dicapai sedangkan peserta didik dapat lebih memahami isi materi dan lebih bersemangat untuk mengikuti pembelajaran dengan menggunakan media yang disediakan.

Buku menjadi salah satu media pembelajaran yang digunakan dalam kemampuan minat baca anak. Buku menjadi sumber pencerdasan bagi kehidupan manusia. ${ }^{3}$ Buku tidak selalu mengandung informasi yangtercetak dengan tulisan dan garis tetapi juga bisa bergambar yang dapat dijadikan alternatif dalam pembelajaran. Contohnya buku cerita bergambar yang dapat menarik perhatian peserta didik dalam pembelajaran. Sudah terbukti adanya bahwa cerita sangat disenangi peserta didik ataupun orang dewasa disertai dengan gambar yang membuat bahan bacaan menjadi tidak monoton.

Buku cerita bergambar sendiri dipilah untuk alternatif media yang menarik dikarenakan rata-rata peserta didik lebih menyukai melihat bahan bacaan yang terdapat gambar dan membacanya di perpustakaan sekolah, meskipun peserta didik tidak mengetahui isi dari buku tersebut tetapi adanya gambar menariknya untuk membaca. Buku tidak selalu mengandung informasi yang tercetak dengan tulisan dan garis tetapi juga bisa bergambar yang dapat dijadikan alternatif dalam pembelajaran. Contohnya buku cerita bergambar yang dapat menarik perhatian peserta didik dalam pembelajaran.

Buku cerita bergambar juga memiliki beberapa kelebihan diantaranya membantu

\footnotetext{
${ }^{1}$ Thosporn Sangsawang, "Kerangka Desain Instruksional Untuk Media Pendidikan, Instructional Design Framework For Education Media (Thailand:Procedia, 2015),.h.65

${ }^{2}$ Sadirman, Interaksi dan Motivasi Belajar-Mengajar, (Jakarta: Rajawali Pers, 2016), h.20

3 Agus Sumitra, Nita Sumini "Peran Guru Dalam Mengembangkan Kemampuan Minat Baca Anak

Usia Dini Melalui Metode Read Read Aloud”.Jurnal Ilmiah Potensia. Volume 4, Nomor 2.H.116.
} 
perkembangan emosi peserta didik, merasa gembira, peserta didik juga mengetahui tentang dunia serta dapat menstimulasi imajinasinya. ${ }^{4}$ Dapat disimpulkan bahwa buku cerita bergambar dapat menarik perhatian peserta didik untuk belajar dan buku cerita ini juga tidak hanya berupa paragraf tetapi juga bergambar. Buku cerita bergambar untuk membantu merangsang dan memperkaya imajinasi pada anak.

Selain itu Mitchell dalam Burhan Nurgiantoro, mengatakan bahwa buku cerita bergambar merupakan buku yang menampilkan gambar dan teks serta keduanya saling berkaitan. Gambar saja tidak cukup untuk mengisahkan sebuah cerita tanpa teks untuk itu gambar dan teks dalam buku cerita bergambar saling melengkapi satu sama lain. Lukens menguatkan bahwa ilustrasi gambar dan tulisan merupakan dua media yang berbeda, tetapi dalam buku cerita bergambar keduanya secara bersama membentuk satu kesatuan. ${ }^{5}$ Memilih media buku cerita bergambar karena pada tahap anak usia sekolah dasar (usia 7-11 tahun), anak mengalami tahap operasional konkret, di mana seorang anak akan lebih mudah memahami materi pelajaran jika mereka menggunakan sumber belajar atau media yang dapat dilihat dan dipegang secara langsung.

Lingkungan hidup adalah sistem yang merupakan kesatuan ruang dengan semua benda, daya, keadaan, dan makhluk hidup termasuk didalamnya manusia dengan perilakunya yang mempengaruhi kelangsungan kehidupannya dan kesejahteraan manusia serta makhluk hidup lainnya. ${ }^{6}$ Dari definisi di atas, terlihat jelas bahwa makhluk hidup khususnya manusia merupakan pihak yang selalu memanfaatkan lingkukngan hidupnya, baik dalam hal repirasi, pemenuhan kebutuhan pangan, papan dan lain-lain. Oleh karena itu, manusia sangat membutuhkan lingkungan hidup untuk memenuhi kebutuhan seharihari. Manusia sebagai makhluk hidup yang unggul di dalam ekosistemnya, memiliki daya bereaksi dan mengkonsumsi sebagai sumber daya alam bagi kebutuhan hidupnya. Gambar yang terdapat di dalam buku cerita bergambar berfungsi untuk mengilustrasikan penokohan, latar, dan kejadian-kejadian yang digunakan guna membangun alur sebuah cerita. Paduan gradasi warna dapat memberikan kekuatan pengilustrasian dalam buku cerita bergambar. ${ }^{7}$ Pendidikan lingkungan hidup di lingkungan sekolah merupakan modal

\footnotetext{
${ }^{4}$ Eni Suryaningsih, Laila Fatmawati, "Pengembangan Buku Cerita Bergambar Tentang Mitigasi Bencana Erupsi Gunung Api Untuk Siswa Sd". Jurnal Profesi Pendidikan Dasar. Volume 4, Nomor 2, e-ISSN:2503-3530, (Desember 2017), h.113.

${ }^{5}$ Burhan Nurgintoro, Sastra Anak Pengantar Pemahaman Dunia Anak, (Yogyakarta:Penerbit Gajah Mada University Press, 2019), h 184

${ }^{6}$ Manik, Pengelolaan, Lingkungan Hidup, (Jakarta: Putra Grafika, 2018), h. 31.

${ }^{7}$ Nurul Hidayah, Pembelajaran Bahasa Dan Sastra Indonesia Untuk SD, (Yogyakarta:Penerbit Pustaka Pranala, 2019), h.156-157.

52 | Jurnal Auladuna
} 
dasar bagi pembentukan etika lingkungan pada generasi yang akan datang. ${ }^{8}$

Menurut Beans dalam Udin Syaefudin pembelajaran tematik sebagai upaya untuk mengintegrasikan perkembangan dan pertumbuhan peserta didik dan kemampuan pengetahuannya. ${ }^{9}$ Pembelajaran tematik merupakan pembelajaran yang memanfaatkan tema dalam penyampaian materi, tema berperan sebagai pemersatu kegiatan pembelajaran yang memadukan beberapa mata pelajaran sekaligus memilih sebuah tema yang dapat mempersatukan indikator dari beberapa mata pelajaran SD. Pembelajaran tematik merupakan kurikulum 2013, dimana pendidik dituntuk untuk kreatif dan menjadi motivator sekaligus fasilitator untuk peserta didiknya. Dalam kurikulum 2013, pendidik diberi keleluasan dalam menilai dengan objektif, namun pendidik tidak boleh terfokus dengan satu aspek kognitif (Pengetahuan), melainkan dengan aspek afektif (sikap) dan aspek psikomotor (keterampilan). Kelebihan dari kurikulum 2013 itu sendiri adalah peserta didik bebas memilih untuk mengembangkan minat dan bakatnya, karena di kurikulum 2013 peserta didik diberi kebebasan dalam berkarya namun tetap dalam pengawasan pendidik.

Jenis yang digunakan peneliti adalah menggunakan penelitian dan pengembangan atau yang disebut istilah Research Development (R\&D). Hasil akhir penelitian ini yaitu menghasilkan produk. Pada penelitian ini menggunakan metode dari Borg and Gall dengan langkah-langkah atau prosedur penelitian. ${ }^{10}$

\footnotetext{
${ }^{8}$ Rachmat Mulyana, Penanaman Etika Lingkungan Melalui Sekolah Perduli DanBerbudaya Lingkungan, Jurnal Tadris Unimed Vol.6 No.2, Desember 2019. h. 180.

${ }_{9}^{9}$ Abd Kadir dan Hanun Asrohah, Pembelajaran Tematik, (Jakarta: Rajawali Pers, 2015),hlm 15

${ }^{10}$ Sugiono, Metode Penelitian Pendidikan Pendekatan Kuantitatif, Kualitatif, dan R\&D, Bandung: Alfabeta, 2018), h.407
} 


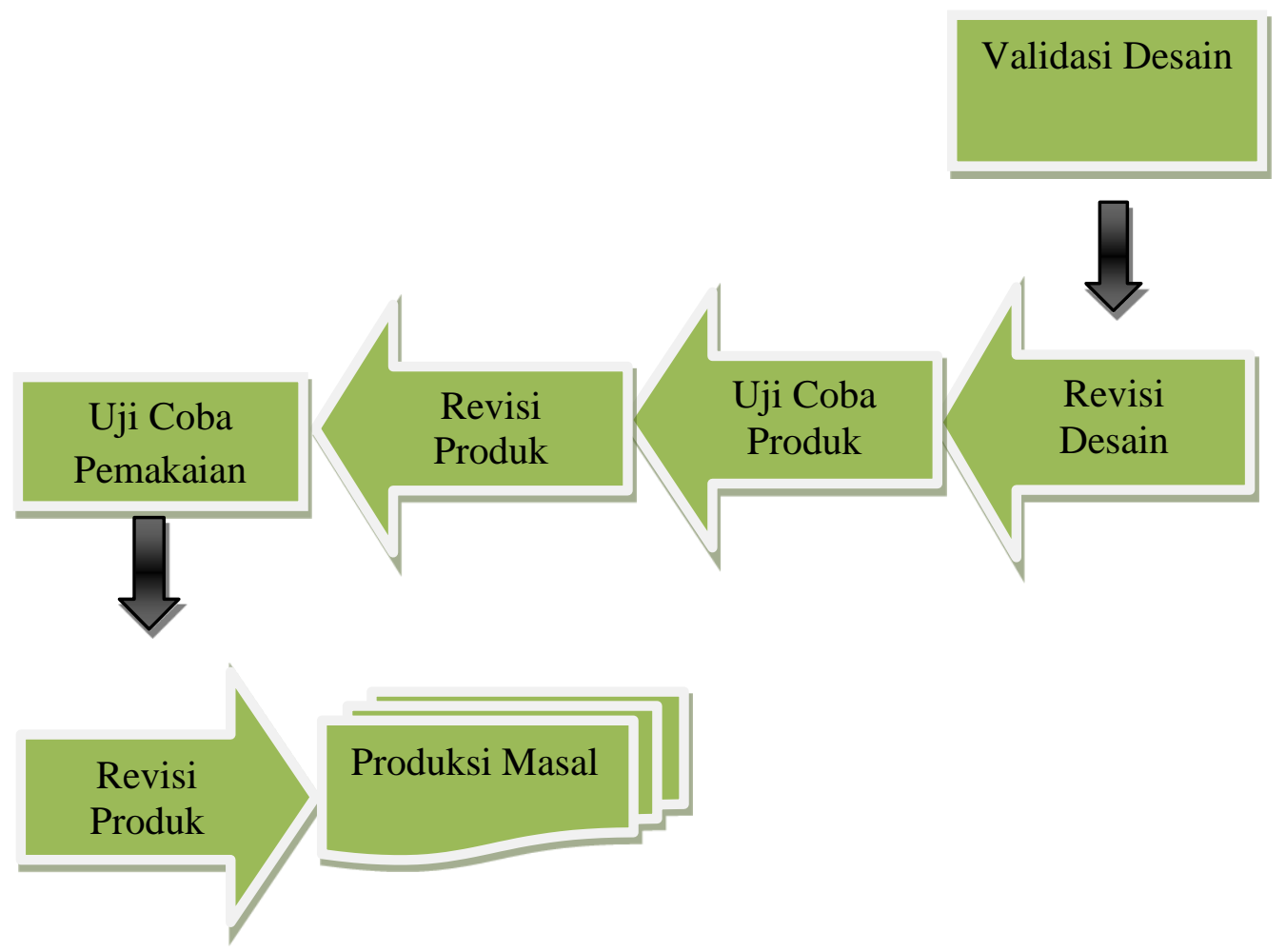

Pada prosedur R \& D Model Borg and Gall di atas terdapat 10 langkah, namun pada tahapan ini peneliti membatasi langkah-langkah di atas hanya menjadi 7 langkah dikarenakan mempersingkat waktu dan tidak memerlukan biaya yang sangat banyak, adapun langkah-langkah yang diambil peneliti yaitu: (1) Potensi dan Masalah (2) Pengumpulan Data (3) Desain Produk (4) Validasi Desain (5) Revisi Desain (6) Uji Coba Produk (7) Revisi Produk.

${ }^{11}$ Sugiono, Ibit, h. 409

54 | Jurnal Auladuna 


\section{PEMBAHASAN}

Uji produk pada penelitian ini dilakukan pada dua sekolah, yaitu SDN Wates Lampung Tengah dan MI Al-Hikmah Bandar Lampung. Hasil utama dari penelitian dan pengembangan ini adalah dengan menghasilkan produk berupa media buku cerita pada pembelajaran tematik di kelas II SD/MI. Penelitian dan pengembangan yang peneliti dilaksanakan yaitu menggunakan langkah-langkah penelitian dan pengembangan yang diadaptasi dari Sugiyono yang akan dilaksanakan dari tahap satu hingga tahap ketujuh. Data yang diperoleh dari hasil setiap tahapan penelitian dan pengembangan yang akan dilaksanakan lebih rinci dibahas sebagai berikut:

1. Potensi dan Masalah

Permasalahan yang terdapat dalam penelitian ini sekolah hanya menggunakan buku paket tematik dan tidak ada media alternatif lain yang dipakai untuk proses pembelajaran. Penggunaan media yang belum inovatif menjadikan proses belajar mengajar kurang menarik, hal ini yang sering membuat siswa menjadi bosan dalam proses pembelajaran. Dengan ini, memerlukan adanya pengembangan media pembelajaran yang baru yang variatif, inovatif dan kontekstual.

2. Pengumpulan Data

Proses yang dilakukan berikutnya yaitu mencari data dan mengumpulkannya. Pada tahapan pengumpulan informasi data dari buku cerita bergambar peneliti sebelumnya melihat materi yang terdapat di buku tematik yang digunakan pada kelas II SD/MI dan menghubungan dengan lingkungan hidup pada proses penyusunan buku cerita bergambar.

3. Desain Produk

Pada proses pengembangan buku cerita bergambar desain gambar dibuat dan di sesuaikan dengan isi cerita yang akan disampaikan dengan nuansa lingkungan hidup. Ukuran buku cerita yang dibuat adalah A5 dan dicetak dengan menggunakan kertas art paper. Bagian sampul baik depan maupun sampul belakang di desain mengikuti tema judul yang diangkat. Paduan warna yang menarik juga diberikan pada buku cerita bergambar ini., 

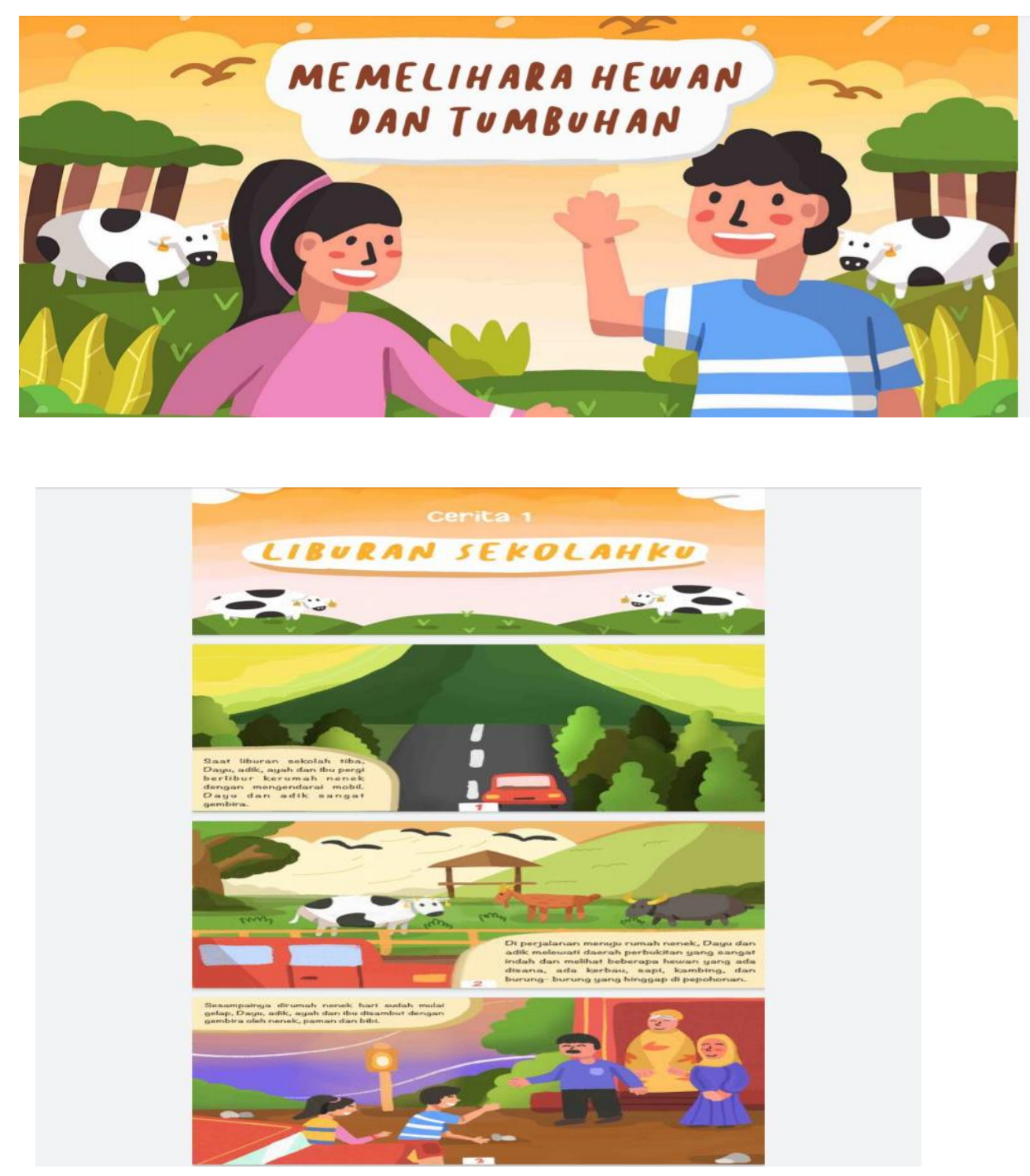

4. Validasi Desain

Validasi ahli ini dilakukan dengan tujuan agar produk buku cerita bergambar berbasis lingkungan hidup yang dikembangkan peneliti mendapatkan pertanggungan yang menyatakan bahwa produk awal yang akan dikembangkan efektif diuji cobakan terhadap peserta didik. Tahapan awal yaiyu melakukan validasi terhadap 2 ahli bahasa yaitu dengan Ibu Nurul Hidayah, M.Pd sebagai sekretaris jurusan PGMI dan Bapak Nasir, M.Pd, selanjutnya 2 ahli materi yaitu dengan Ibu Yuliyanti, M.Pd selaku dosen PGMI dan Ibu Diah Rizky, S.Pd yamg selanjutnya adalah 2 tahap media yang di validasi oleh Bapak Anton Trihasnanto, M.Pd dan Ibu Ayu Reza Ningrum, M.Pd selaku dosen PGMI UIN Raden Intan Lampung. 


\section{Revisi Desain}

Setelah media pembelajaran sudah selesai divalidasi oleh dosen para validator ahli, data yang didapat pada tahap ke-1 belum sepenuhnya layak untuk digunakan untuk bahan belajar peserta didik, maka dilakukan revisi pada pembuatan produk media pembelajaran.

Gambar 2

\section{Grafik Penilaian Validasi Ahli Media Tahap 1}

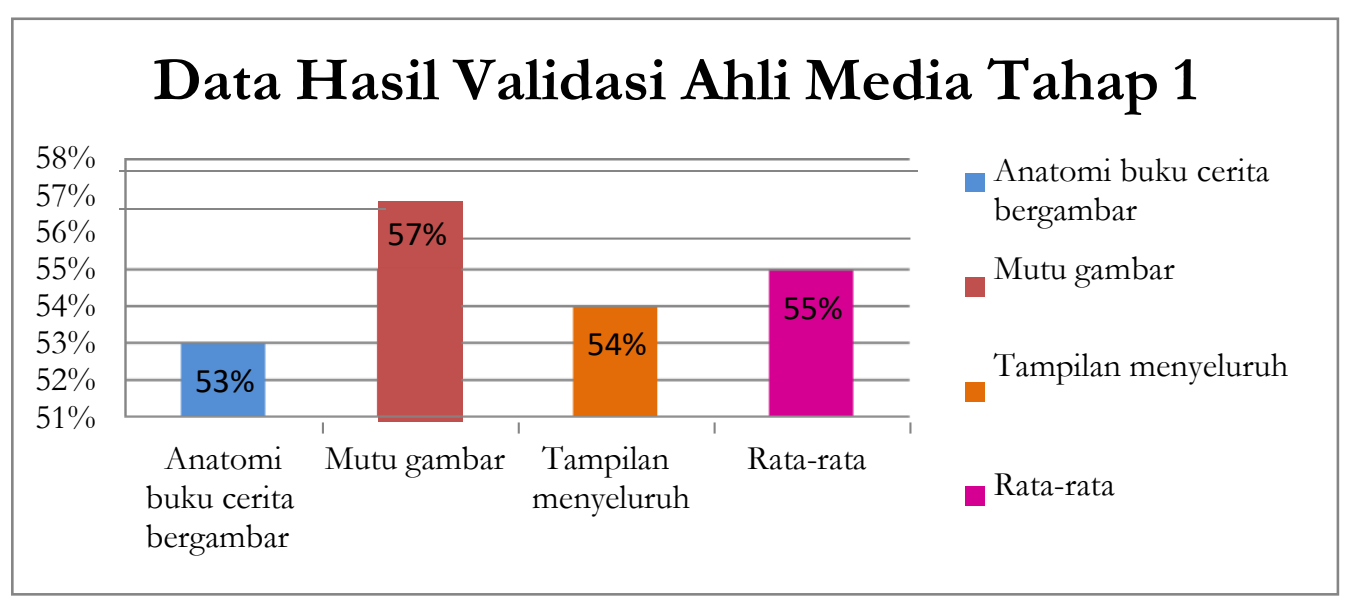


Pada validasi tahap ke-2 dengan produk yang sudah direvisi maka data yang didapat sesuai keinginan dinyatakan valid dan layak untuk digunakan oleh pihak pengajar sebagai alat ataupun bahan belajar- mengajar.

Gambar 3

Grafik Penilaian Validasi Ahli Media Tahap 2

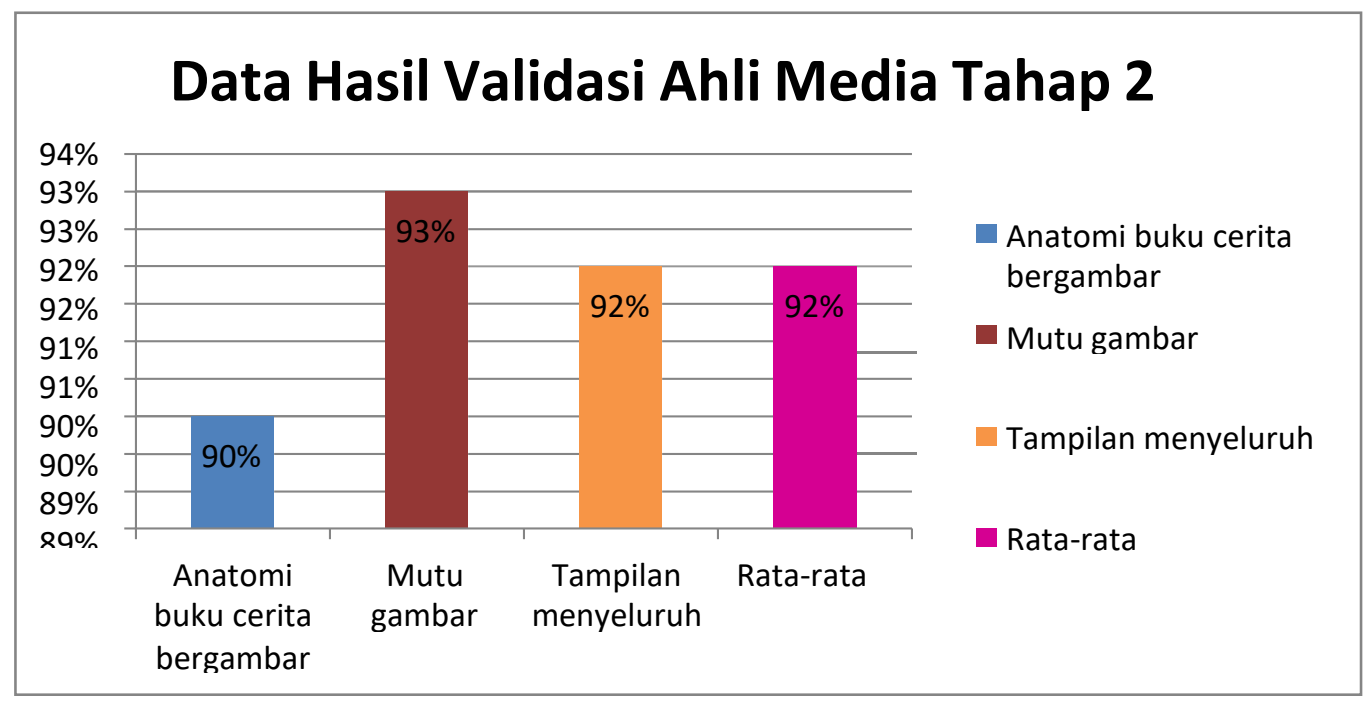

6. Uji Coba Produk

Uji coba lapangan terhadap media buku cerita bergambar berbasislingkungan hidup pada tema 6 peserta didik kelas II MI Al-Hikmah Bandar Lampung dan SDN Wates Lampung Tengah. Uji coba dilakukan dalam dua tahap yaitu uji coba kelompok kecil yang dilakukan di SDN Wates Lampung Tengah danUji coba kelompok besar dan dilakukan di MI Al-Hikmah Bandar Lampung.

Sebelum uji coba produk terhadap peserta didik maka dilakukan validasi oleh pendidik agar mengetahui layak atau tidaknya produk untuk di uji cobakan. Berikut hasil data gambar grafik penilaian validasi pendidik.

\section{Gambar 4}




\section{Grafik Penilaian Validasi Pendidik}

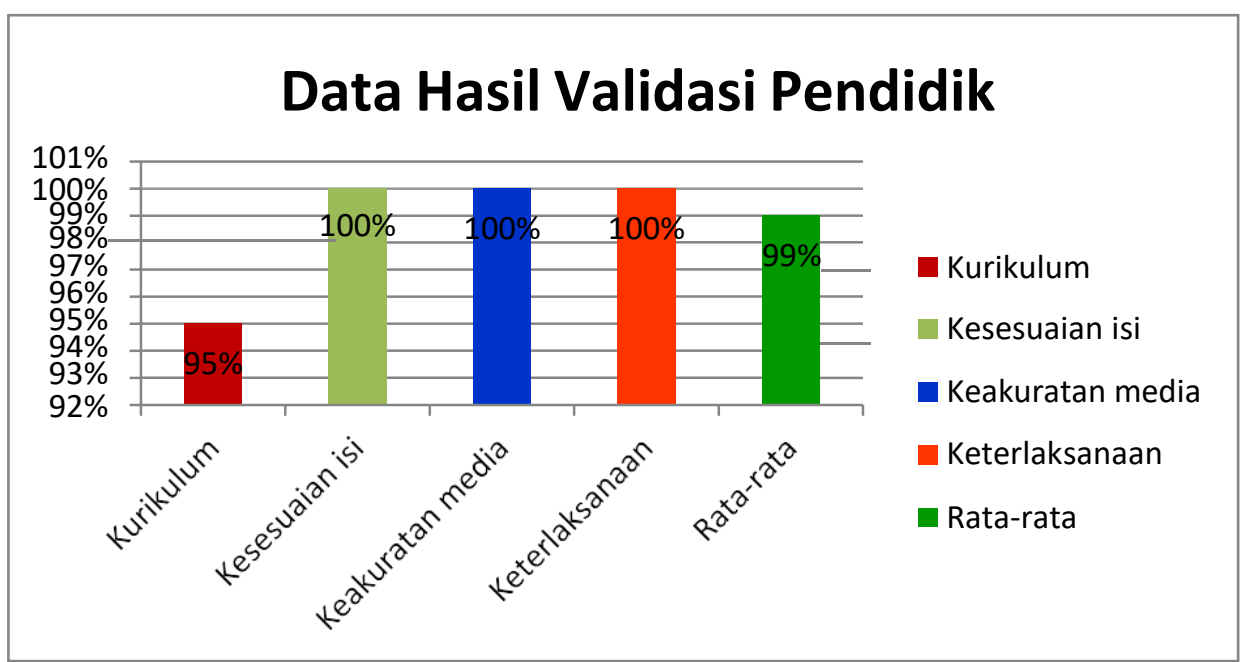

\section{Uji Coba Skala Kecil}

Berdasarkan hasil uji coba kelompok kecil yang dilakukan di SD Negeri Wates Lampung Tengah, pada aspek kualitas isi dengan 5 indikator mendapat skor rata-rata 4,4 dengan persentase 89\%, aspek tampilan media dengan 4 indikator mendapat skor 4,5 dengan persentase 91\%, aspek kualitas teknis dengan 2 indikator mendapat skor 4,5 dengan persentase 91\%. Sehingga memperoleh skor rata-rata dari keseluruhan aspek adalah 90\% dengan kategorisangat layak.

\section{Uji Coba Skala Besar}

Berdasarkan hasil uji coba kelompok besar yang dilakukan di MI Al- Hikmah Bandar Lampung, pada aspek kualitas isi dengan 5 indikator mendapat skor rata-rata 4,5 dengan persentase $90 \%$, aspek tampilan media dengan 4 indikator mendapat skor 4,4 dengan persentase $89 \%$, aspek kualitas teknis dengan 2 indikator mendapat skor 4,4 dengan persentase 88\%. Sehingga memperoleh skor rata-rata dari keseluruhan aspek adalah 89\% dengan kategorisangat layak. 
Ayu Nur Shawmi,

Nurhaidah Widiani,

Afni Novita Dewi

\section{PENUTUP}

Pengembangan buku cerita bergambar berbasis lingkungan hidup pada pembelajaran tematik kelas II SD/MI pada tema merawat hewan dan tumbuhan menggunakan Research and Development model Brog and Gell yang dimodifikasi oleh sugiono yang melalui 7 tahapan yaitu: potensi dan masalah, pengumpulan data, desain produk, validasi desain, uji coba produk dan revisi produk. Kualitas dan keefektifan produk berdasarkan validasi sangat layak digunakan dengan validasi beberapa ahli meliputi ahli bahasa memperoleh nilai rata-rata 90\% dengan katagori sangat layak, validasi materi dengan rata-rata 97\% dengan katagori sangat layak dan validasi media dengan ratarata 92\% dengan katagori sangat layak. Rata-rata uji berskala kecil memperoleh rata-rata 90\% dengan katagori sangat layak dan uji skala besar memperoleh rata-rata $89 \%$ dengan katagori sangat layak.

\section{DAFTAR PUSTAKA}

Abd Kadir dan Hanun Asrohah, Pembelajaran Tematik, (Jakarta: Rajawali Pers, 2015)

Agus Sumitra, Nita Sumini "Peran Guru Dalam Mengembangkan Kemampuan

Minat Baca Anak Usia Dini Melalui Metode Read Read Aloud”.Jurnal Ilmiah Potensia. Volume 4, Nomor 2.

Burhan Nurgintoro, Sastra Anak Pengantar Pemabaman Dunia Anak, (Yogyakarta:Penerbit Gajah Mada University Press, 2019)

Eni Suryaningsih, Laila Fatmawati, "Pengembangan Buku Cerita Bergambar Tentang Mitigasi Bencana Erupsi Gunung Api Untuk Siswa Sd". Jurnal Profesi Pendidikan Dasar. Volume 4, Nomor 2, e-ISSN:2503-3530, (Desember 2017)

Manik, Pengelolaan, Lingkungan Hidup, (Jakarta: Putra Grafika, 2018),

Nurul Hidayah, Pembelajaran Bahasa Dan Sastra Indonesia Untuk SD, (Yogyakarta: Penerbit Pustaka Pranala, 2019)

Rachmat Mulyana, Penanaman Etika Lingkungan Melalui Sekolah Perduli Dan Berbudaya Lingkungan, Jurnal Tadris Unimed Vol.6 No.2, Desember 2019.

Sadirman, Interaksi dan Motivasi Belajar-Mengajar, (Jakarta: Rajawali Pers, 2016), Sugiono, Metode Penelitian Pendidikan Pendekatan Kuantitatif, Kualitatif, dan R\&D, Thosporn Sangsawang, "Kerangka Desain Instruksional Untuk. Media Pendidikan, Instructional Design Framework For Education Media (Thailand:Procedia,2015).

60 | Jurnal Auladuna 